\title{
Entrepreneurial Recovery From Natural Disaster: A Consideration Of Influential Factors
}

Katherine A. Fraccastoro, Lamar University, USA

\begin{abstract}
This paper contains interviews with five entrepreneurs affected by Hurricane Rita in the Southeast Texas Region. It qualitatively examines the recovery efforts of these entrepreneurs including the extent to which government assistance was utilized in their recovery efforts. The purpose was to determine if there were any specific factors that helped or hindered in the recovery effort. Factors considered in this study include the length of time in business, type of customer served, amount of damage to the business, length of down time due to the hurricane, types of recovery assistance utilized, and the entrepreneurs' thoughts on keys to recovery. The study finds several interesting trends. First, length of time in business does not seem to be a factor in recovery after a natural disaster. Instead, the passion for the business or drive or motivation to succeed appears to be a key to overcoming adversity. Second, most entrepreneurs did not utilize any type of government recovery assistance. Third, it does appear that the types of customers the entrepreneurs service do play a role in the speed with which the entrepreneurs were able to fully recover. The speed of economic recovery also appears to be influenced by how quickly all or part of the business is able to reopen.
\end{abstract}

Keywords: Entrepreneurship, natural disaster recovery, government recovery assistance

\section{INTRODUCTION}

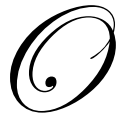

n August 29, 2005 Hurricane Katrina hit the Gulf Coast, destroying the Mississippi coastal region. The effects from the hurricane caused the levies to break in the New Orleans area as well, creating massive devastation. On September 24, 2005, Hurricane Rita tore through the southwestern parts of Louisiana and southeast Texas demolishing thousands of homes and businesses. According Richmond (2006), it is estimated that over 81,000 businesses were affected by Hurricanes Katrina and Rita. In these natural disasters, like others, many residents and business owners were left with little or nothing and could only wonder how to start over or rebuild.

In times of disaster, such as the 2005 hurricanes that hit the Gulf States region, one would expect individuals and businesses look to the government for help. The government is supposed to provide much needed relief and aid to individuals and businesses alike. One would think that the types of relief available and the ease with which businesses can access this relief may determine the ability of businesses to recover from these unexpected events. It is interesting to examine the extent to which businesses look for government assistance in their recovery efforts. Does the government provide useful assistance to businesses when disasters strike? Are businesses willing or able to use the assistance the government has available, or do they devise their own solutions to their recovery problems? This study examines the recovery efforts of several entrepreneurs involved in Hurricane Rita, including the extent to which government assistance was utilized in their recovery efforts.

\section{GOVERNMENT ASSISTANCE}

Presently, the only types of assistance the government provides to business owners faced with the aftermath of disasters are loans through the Small Business Administration. The loan materials are distributed through FEMA 
(Federal Emergency Management Administration). The loans are of two types-economic injury and physical disaster. All documentation of these loans must be completed by the business owner and submitted for processing. The SBA must then process the loan application and determine if the business owner qualifies for assistance. In many cases in the aftermath of Hurricane Rita, business owners were turned down for various reasons, including incomplete information (Tozzi, 2007). In fact, many business owners actually had difficulty filling out the paperwork because much of the information needed for the applications was in their respective businesses in the towns that were either not allowing citizens to return or were destroyed (Tozzi, 2007). Many owners found the process of applying for the loan to be prohibitive and opted to handle matters themselves without any government assistance. The SBA states that it is unable to act on loans with incomplete information and can only act once the information has been provided (Tozzi, 2007).

\section{BACKGROUND RESEARCH ON BUSINESS DISASTER RECOVERY}

Much of the research in the area of disaster recovery for businesses has dealt with the planning phase of the business. Several researches have examined the need for a disaster or back-up plan. According to Kim Krisberg (2007), detailed preparedness plans can lessen the aftermath of a disaster by speeding the recovery process. Companies that had preparedness plans were more likely to reopen after a disaster than those without a plan. Bases on information in the Massachusetts Banker (2007), $60 \%$ of businesses that experience disaster and do not have a sound recovery plan go out of business within 24 months.

According to several authors (Krisberg 2007, Runyan 2006, and Thomas 2006), small businesses are less likely to have plans or procedures in place to deal with unexpected events like natural disasters. They are vulnerable to cash flow interruptions and infrastructure problems and are likely to have difficulty accessing capital for recovery.

Various papers also make recommendations on actions business owners can take to be better prepared for a disaster (Graham 2007, Krisberg 2007, Massachusetts Banker 2007, Thomas 2006, Andel 2005).

\section{STUDY}

This paper explores the role government assistance has played to aid entrepreneurs in the recovery of the Hurricane Rita in Southeast Texas. The actual courses of action entrepreneurs have taken in the wake of these natural disasters will also be examined.

For this study, several entrepreneurs affected by Hurricane Rita in 2005 were interviewed. They were asked to discuss (1) the affect the hurricane had on their business in the weeks and months after the storm, (2) what types of aid they needed and where they found it, (3) and what impact, if any, the hurricane is still having on their business almost three years later. The type of business, type of customers served, length of time in business, access to capital (and types of capital), length of time the business was closed due to hurricane issues and other factors are also explored.

Data was collected via personal interviews with the researcher. The entrepreneurs' stories follow.

\section{ECHO IMPACT ADVERTISING AND DESIGN}

Ryan Ferguson is the owner/operator of Echo Impact Advertising and Design which is a graphic design service specializing in printing, business promotion, and web design. Echo Impact began in September 2004 while Mr. Ferguson was still working for another company. He left his job to go full-time in the home-based business in April 2005. Hurricane Rita hit five months later, damaging his home. At the time, Mr. Ferguson was servicing companies on an as needed basis. He had no retainers and was being paid by the job. He serviced all types of businesses in many different areas including entertainment, newspapers, and restaurants. Most were small to medium sized businesses. Work stopped once the hurricane hit. No one needed his services because they were all concerned about their own recovery. This type of service is not considered a necessity in times of trouble. 
Mr. Ferguson left during the hurricane and was gone for approximately three months. This was the length of time it took to get all services up to the area (including internet). During this time he continued to work on the business as much as possible because the business requirements were a phone and computer. He lost all customers temporarily, so he also took on temporary work at Southern Methodist University performing marketing, graphic design and web design services. When demand for this business returned initially, Mr. Ferguson's customers were interested in promote the fact that they were now open after the hurricane. Mr. Ferguson said that his business came back strong after the hurricane because of the growth in the Southeast Texas area. He felt that it did take about nine months for the business to fully recover from the effects of the hurricane.

When asked if there were any factors he felt contributed to his ability to rebuild after the hurricane, Mr. Ferguson said that he thought having low overhead helped his ability to continue the business during the lean times after the hurricane and that his motivation and persistence to want the business to succeed were driving forces behind its success. Mr. Ferguson did know about the government loans that were available, but opted not to use them because he felt the paperwork was too complicated and confusing to fill out and it was not worth the effort. He used temporary work to supplement his income and help him rebuild.

\section{GOPHER INDUSTRIAL, INC}

David Jones and David Sandlin are business partners in Gopher Industrial, Inc which provides all types of industrial materials to business and consumers through the internet and a store front. At the time of the hurricane, Gopher Industrial was a new internet only company that had begun accepting internet sales about three weeks before the hurricane hit. When Hurricane Rita was projected to hit the area, they packed up the computers and servers and moved everything to San Antonio, Texas. They stayed for three months. There was damage to the building they were leasing and the entire infrastructure necessary to run their business was gone (internet, phones, etc.).

They were in the planning stages for opening the store front at the time of the hurricane. The hurricane slowed their ability to go to market sooner and they estimate they lost as much as one million dollars due to their inability to get back into the area and bring in the merchandise necessary to help with the rebuilding efforts in the business market. While the web service continued to operate and generate sales, the local store front was delayed by about six months due to damages. As soon as the local store front was opened and they were logistically able to bring in stock, business was strong. Mr. Jones and Mr. Sandlin felt that it took their business about one year to fully recover from the effects of the hurricane. They felt the keys to the success of their business in their hurricane recovery were their internal drive to succeed, their ability to maintain the web side of the business to keep sales coming in, and the local customers that gave them a chance due to their investment in the community. Gopher Industrial, Inc. is a strong supporter of the local community.

When asked about the government loan assistance provided for hurricane recovery, Mr. Jones and Mr. Sandlin stated that they only found out about those after the hurricane, but that it was simply getting another loan and they felt that they would be unable to substantiate it. They were a new business, not yet firmly established at the time and they really did not want to take on any more debt. They chose instead to focus on generating sales through their website by working 18-20 hours per day to get data out on the web.

\section{HORIZONS DANCE AND GYMNASTICS}

Cheri Billiot, along with her husband Orlean, are the owners of Horizons Dance and Gymnastics. Cheri has been in business for 25 years providing opportunities for children 18 and under to learn various forms of dance and gymnastics. When Hurricane Rita hit, the business closed down and Mrs. Billiot and her family evacuated. The business remained closed for about eight weeks. While the building was not severely damaged, there was no electricity, making it impossible to reopen. Since this service is not considered a necessity, Horizons did lose about 10 percent of the students who did not return after the hurricane. It took an entire dance season (approximately one year) for business to return to pre-hurricane levels. Mrs. Billiot did try to work with the customers who came back immediately following the hurricane by charging less for recital fees and being more flexible on payment for monthly dues. 
During the interim between the storm and reopening the business, Mrs. Billiot did not work; however, she did have supplemental unemployment benefits that she received to help pay some of the expenses. The insurance coverage for the unemployment and the business structure and contents was not what Mrs. Billiot expected. She now has more insurance coverage for the business. Mrs. Billiot felt that being a family business aided in their ability to recover from this natural disaster. She said it was helpful to have someone with whom to talk and work out the business issues that arose due to the hurricane. She also felt that having loyal customers who came back as soon as the doors were reopened was beneficial to continuation of the business. She thought it was important to get the facility reopened quickly because it is the kind of business that gives kids something to do that is fun.

When asked about the government loans, Mrs. Billiot replied that she was aware of the loan program, but did not want to incur more debt with another loan. Instead, she and her husband utilized the insurance money they received to rebuild and supplemented that with personal income.

\section{LOOKIN GOOD FAMILY HAIR CARE CENTER}

Paul Burch is a co-owner in Lookin Good Family Hair Care Center which is one-half hair salon and onehalf clothing and accessory boutique. Lookin Good has been in business since 1976. The business leases space in a shopping center that was devastated by Hurricane Rita (see Figure 1). The entire facility and contents were a total loss for Mr. Burch. While the hair salon did have property coverage, the boutique side did not.

Mr. Burch evacuated during the time the hurricane hit and returned to town immediately following the storm. The store was closed for five weeks, which is the amount of time it took to get services such as electricity restored and to clean out the store and have plywood erected to wall in the storefront. The business did reopen with interior damage still present. Mr. Burch felt that the business did recover fairly quickly from the effects of the hurricane, even with the damages they incurred. He said that customers returned to the business as soon as everyone returned to town. Immediately following the storm, the employees of Lookin Good were able to receive continuance insurance for unemployment to help pay bills while generation of income was not possible. Mr. Burch felt that the keys to recovery for his business were his ability to get the business reopened quickly and customers returning immediately.

When asked about the government loans, Mr. Burch replied that he did not know about them immediately, but did find out about them later. He said he did not utilize the loans, nor would he have used them if he had known about them sooner. Mr. Burch preferred to use the money received from the insurance and his own personal investment to rebuild.

\section{SPANKY'S RESTAURANT}

Mike LeMoine is the owner of Spanky's Restaurant which is a bar and restaurant serving a variety of food and drink to customers of all ages. Spanky's has been in existence since February 28, 1989. It is a free-standing facility on the main street in the city of Orange, Texas. The building had significant damage due to Hurricane Rita. The roof was damaged and water got into the building damaging the kitchen equipment and carpets. Mr. LeMoine returned immediately after the hurricane to inspect the damage to his property. The bar section of the restaurant had only minimal damage and reopened within one month. Due to a lack of workers, he was unable to even begin repairing the restaurant side of the business for about six weeks. The restaurant was a complete teardown on the interior, new equipment had to be ordered, and finding the necessary labor for things like roofing was very difficult. Mr. LeMoine did all of the demolition himself and was finally able to find qualified contractors through friends and loyal customers.

Mr. LeMoine was in a unique situation in which his sister had a small restaurant facility that was not being fully utilized at the time that was undamaged in the storm. He was able to get some of his employees back to work within a few days of the storm by reopening temporarily in this location with generators and propane. Business for this temporary location was very good because there was a significant lack of places to eat for workers in town helping with clean-up efforts. This helped keep some funds coming into the business. The actual restaurant did not 
open until January 10, 2006, almost four months after the storm. There was still damage to the facility when it was reopened. According to Mr. LeMoine, customers came back immediately. He held a customer appreciation time for four hours during which all food was free.

The road to recovery for Spanky's was difficult and there were times Mr. LeMoine questioned whether or not he would make it back. He had difficulty with his insurance company and needed money to rebuild. He was able to obtain a bank loan from a neighbor who was the president at a local bank that enabled him to start repairs. Eventually the insurance paid the appropriate damages; however, the insurance coverage was not sufficient for all of the business needs. Mr. LeMoine also was able to receive an SBA Business loan through FEMA for physical disaster. He said the paperwork was tedious and time-consuming, but that he was not going to give up on it. The money allowed him to rebuild his kitchen and make the other necessary repairs that were not covered by insurance. He said this entire experience made him more confident in his abilities to handle difficult business situations. He felt that one of the biggest keys to his ability to return was having someone like his neighbor, who was a home-town banker, who had enough faith in his business to loan him money quickly so he could start the recovery process. Mr. LeMoine said business is better now than before the storm due to all of the recovery still taking place in the area almost three years later and the expansion in industry that has occurred in the area.

\section{CONCLUSIONS}

Based on the information provided by these entrepreneurs, several trends appear to be evident. First, length of time in business does not seem to be a factor in recovery after a natural disaster. Instead, the passion for the business or drive or motivation to succeed appears to be a key to overcoming adversity. Second, most entrepreneurs did not utilize any type of government recovery assistance. Most felt the process was too complicated and not worthwhile. Many did not want to take on new debt that could create difficulties for the business later. Instead they chose to rely on their personal incomes and insurance payments to get them through. The only exception (Spanky's) was the company that needed to do a major structural revision of the interior of the physical facility. The owner felt that the government loan was the best interest rate available and he was not concerned about his business' ability to generate enough revenue to make the loan payments. Thus, it appears that the people for whom the loan program was intended are not very likely to utilize the program.

Third, it does appear that the types of customers the entrepreneurs service do play a role in the speed with which the entrepreneurs were able to fully recover. Businesses that had more diverse consumer target audiences allowed entrepreneurs to recover more quickly than those with more targeted or specialized audiences. The speed of recovery also appears to be influenced by how quickly all or part of the business is able to reopen.

While this study only examines the stories of five entrepreneurs, it does consider (Exhibit 1) the length of time in business, type of customer served, amount of damage to the business, length of down time due to the hurricane, types of recovery assistance utilized, and the entrepreneurs' thoughts on keys to recovery. Studies with larger samples investigating these factors may provide additional insight into what factors truly affect recovery of entrepreneurial firms. All businesses considered in this investigation were successful prior to the natural disaster. Although this study did not fully investigate the economic state of the business prior to the hurricane, it would be interesting to investigate this factor for businesses that did recover and businesses that did not recover to see if it has any influence. Additional studies may also include external factors such as the economy of the area pre- and postdisaster and the amount of industry in the area as well.

\section{AUTHOR INFORMATION}

Katherine Fraccastoro received her Ph.D. from Louisiana State University and is currently an associate professor of Marketing at Lamar University, Beaumont, Texas. Her research interests include consumer behavior issues related to product pricing, cultural acceptance issues, entrepreneurship, and marketing education. She has published several referred papers on these and related issues in conference proceedings and journals such as the Journal of Consumer Behavior, Marketing Letters, Journal of Higher Education Policy and Management, and 
Communications of the Association for Information Systems. Currently Dr. Fraccastoro is the William E. and Katherine F. Fouts Faculty Scholar in Business.

\section{BIBLIOGRAPHY}

1. Andel, Tom (2005), "Katrina and Rita Demand Answers," Paperboard Packaging, October, p. 6

2. Graham, Leigh T. (2007), "Permanently Failing Organizations? Small Business Recovery After September 11, 2001," Economic Development Quarterly, 21, 4, p. 229-314.

3. Krisberg, Kim (2007), "Employer disaster plans crucial to readiness (cover story)," Nation's Health, 37, 4, p. $1-23$.

4. Richmond, Riva (2006), "Enterprise: SBA's Major Role in Gulf Coast Aid Continues; Massive Recovery Efforts For Small Businesses Will Take Years to Finish,” The Wall Street Journal, Eastern Edition, April 18 , p. B10

5. Runyan, Rodney C. (2006), "Small Business in the Face of Crisis: Identifying Barriers to Recovery from A Natural Disaster," Journal of Contingencies and Crisis Management, 14, 1, p. 12-26.

6. Thomas, Dennis (2006), "Business Continuity and the Smaller Company," Credit Control, 27, 7/8, p. 6669.

7. Tozzi, John (2007), "Small Business, Big Disaster," Business Week Online, August 6.

8. Wichmann, Jr., Henry and Kilpatrick, D. J. (2002), "Small business administration business and disaster loans," The CPA Journal, 72, 9, p. 54-59.

9. - -----, (2007), “Disaster Recovery,” Massachusetts Banker, Second Quarter, p. 16.

Figure 1: Lookin Good Hair Salon Hurricane Rita Damage

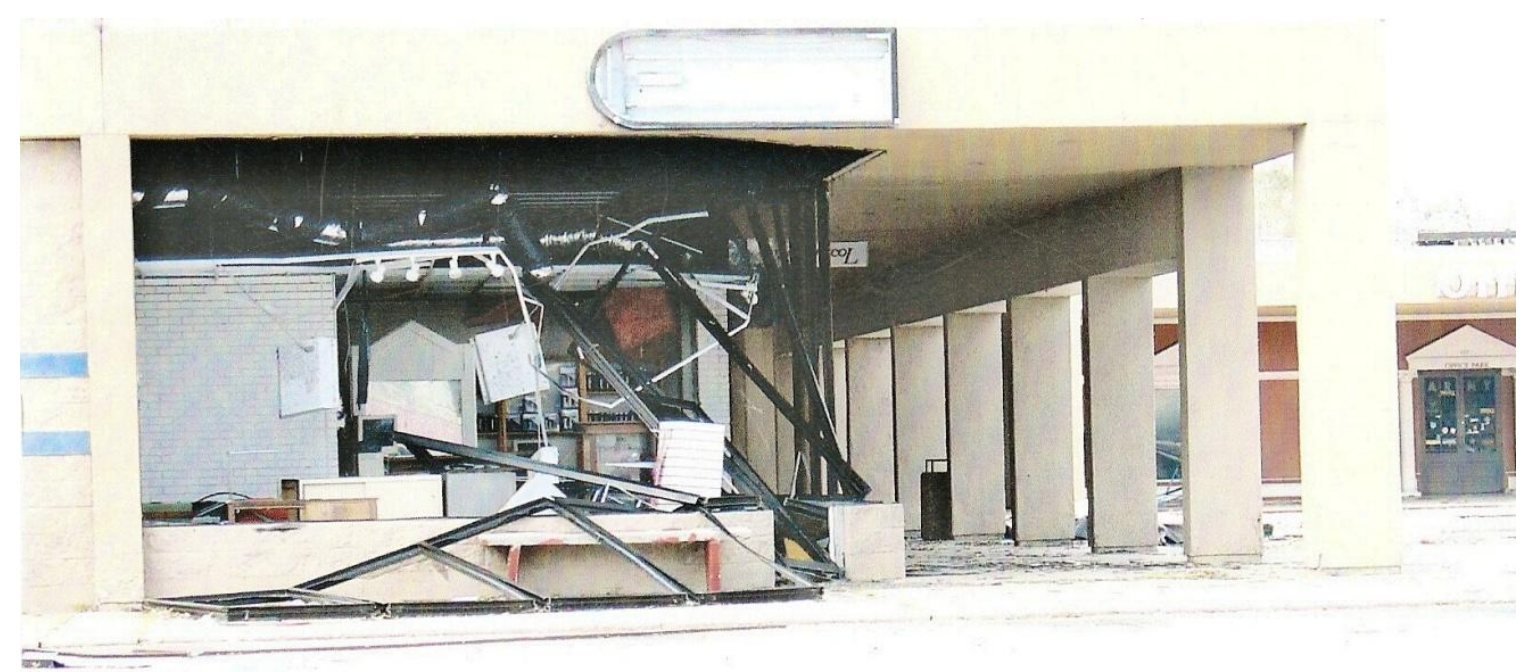

Lookin' Good Family Hair Care Center

September 26, 2005

Hurricane Rita 


\section{Exhibit 1: Key Factors Investigated}

\begin{tabular}{|c|c|c|c|c|c|}
\hline Factors\Business & Echo Impact & $\begin{array}{c}\text { Gopher } \\
\text { Industrial }\end{array}$ & Horizons & Lookin Good & Spanky's \\
\hline $\begin{array}{l}\text { Length of Time in } \\
\text { Business Prior to } \\
\text { Hurricane }\end{array}$ & 17 months & 3 weeks & 22 years & 29 years & 16 years \\
\hline Type of Customers & $\begin{array}{l}\text { Small to medium } \\
\text { sized businesses }\end{array}$ & $\begin{array}{l}\text { Industrial and } \\
\text { consumer } \\
\text { markets }\end{array}$ & $\begin{array}{l}\text { Children ages } 18 \\
\text { and under }\end{array}$ & $\begin{array}{l}\text { Consumers of all } \\
\text { ages }\end{array}$ & $\begin{array}{l}\text { Consumers of al } \\
\text { ages }\end{array}$ \\
\hline $\begin{array}{l}\text { Type of Business } \\
\text { Facility }\end{array}$ & Web-based & $\begin{array}{l}\text { Web-based (at } \\
\text { time of event) }\end{array}$ & Physical Facility & Physical Facility & Physical Facility \\
\hline Time to Reopen & $\begin{array}{l}\text { Did not close/ } 3 \\
\text { months to return } \\
\text { to area }\end{array}$ & $\begin{array}{l}\text { Did not close/ } 3 \\
\text { months to return } \\
\text { to area }\end{array}$ & 8 weeks & 5 weeks & $\begin{array}{l}\text { Bar: } 4 \text { weeks } \\
\text { Restaurant: } 4 \\
\text { months }\end{array}$ \\
\hline $\begin{array}{l}\text { Types of Recovery } \\
\text { Assistance }\end{array}$ & $\begin{array}{l}\text { Temporary Work/ } \\
\text { Personal } \\
\text { Investment }\end{array}$ & $\begin{array}{l}\text { Web sales/ } \\
\text { Personal } \\
\text { Investment }\end{array}$ & $\begin{array}{l}\text { Insurance/ } \\
\text { Personal } \\
\text { Investment }\end{array}$ & $\begin{array}{l}\text { Insurance/ } \\
\text { Personal } \\
\text { Investment }\end{array}$ & $\begin{array}{l}\text { Insurance/ Bank } \\
\text { Loan/ } \\
\text { Government } \\
\text { Loan/ Personal } \\
\text { Investment }\end{array}$ \\
\hline $\begin{array}{l}\text { Length of Time } \\
\text { from Reopening to } \\
\text { Full Business } \\
\text { Recovery }\end{array}$ & 9 months & 1 year & 1 year & Immediate & Immediate \\
\hline
\end{tabular}


NOTES 